\title{
What Western Tourism Concepts Obscure: Intersections of Migration and Tourism in Indonesia
}

\author{
Kathleen M. Adams \\ Loyola University Chicago, kadams@luc.edu
}

Follow this and additional works at: https://ecommons.luc.edu/anthropology_facpubs

Part of the Anthropology Commons, Geography Commons, and the Sociology Commons

This is a pre-publication author manuscript of the final, published article.

\section{Recommended Citation}

Kathleen M. Adams (2020) What western tourism concepts obscure: intersections of migration and tourism in Indonesia, Tourism Geographies, DOI: 10.1080/14616688.2020.1765010

This Article is brought to you for free and open access by the Faculty Publications and Other Works by Department at Loyola eCommons. It has been accepted for inclusion in Anthropology: Faculty Publications and Other Works by an authorized administrator of Loyola eCommons. For more information, please contact ecommons@luc.edu. cc) (i) $\ominus$

This work is licensed under a Creative Commons Attribution-Noncommercial-No Derivative Works 3.0 License. (C) Taylor and Francis, 2020. 


\title{
What western tourism concepts obscure: intersections of migra- tion and tourism in Indonesia
}

\author{
K. M. ADAMS \\ Tourism Geographies \\ [AQ0] \\ Kathleen M. Adams ${ }^{1}[\mathrm{AQ} 1]$ \\ 1. Loyola University Chicago, Chicago, IL, USA[AQ2]
}

CONTACT Kathleen M. Adams kadams@luc.edu Loyola University Chicago, Chicago, IL, USA.

\section{ABSTRACT}

Classic [AQ5]Anglo-European definitions of tourism as recreational travel have hindered more nuanced locally-grounded understandings of travel phenomena elsewhere in the world. Moreover, contemporary global labor and educational mobility have produced novel travel forms and behaviors that straddle the Western categories of "tourist" and "migrant." The purpose of this analysis is to examine Toraja (Indonesia) perspectives on travel which can be instructive for correcting the binary divides between tourism and migration that have long plagued dominant Western models of travel. Drawing from data culled from long-term qualitative fieldwork and online research, I convey three ethnographically-grounded stories of Toraja migrants on return visits to their homeland in order to destabilize Western-centrism in tourism studies. Research findings underscore contemporary travel understandings and practices that do not fit neatly with Western mutually exclusive categories of "tourism" and "migration." These Toraja practices encompass local historical patterns of travel for experiential/financial enrichment (merantau), migration and tourism. This study also advances tourism scholarship by highlighting the importance of local knowledge and demonstrating the value of ethnographic storytelling as a scholarly strategy for destabilizing orthodox Western-centric theoretical understands of tourism. The global significance of this place-based research is that tourism studies can be enriched by widening our lenses to also consider emigrants on return visits to their homelands.

\section{摘要}

欧美地区旅游的回典定回休可旅行，回阻碍了人回界其他地区的旅行回象更回微的、在地性的理解。此外，当前全球回可力和教 育流回?生了跨越西方“游客”和”移民”范畴的新型旅游形式和行回。本研究的目的是可?印度尼西回托拉雅族人旅游的看法, 回 有助于回正回期困回西方主流旅行模式中的旅游和迁移之回的二分法。从回期的定性田野司和在回研究中收集的数据中, 我回达 了三个以民族志回基回的故事, 是关于托拉雅移民回了回覆旅游研究中的西方中心主回而回回故回的故事。研究回果回了当前有关 旅行的理解和可践并不完全符合西方相互排斥的“旅游”和”迁移”回?。回些托拉雅族人的回践包括出于充回旅游体回和回?自由、 迁移和旅游的当地悠久的旅行模式。本研究回通国回地方知可的重要性和展示民族志叙事作回打破正回的西方中心的旅游理?

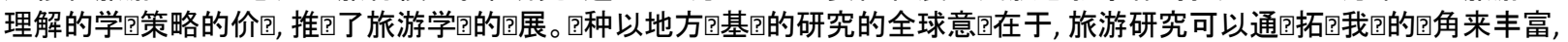
从而也可以考回可民回回他回的祖国。

Keywords: Heritage tourism ; local knowledge ; migration ; story-telling ; critical tourism studies ;Indonesia ;Toraja

关回]: 回? 旅游；当地知回；迁移, 回故事；批判性旅游研究；印尼；托拉雅

\section{Culturally-grounded travel stories, critical tourism studies and kudzu}

The recent critical turn in tourism studies underscores the need for more systematic examinations of how both the practice of tourism and our analyses of it are embedded in asymmetrical power relations and hegemonic discourses 
(Ateljevic et al., 2007; 2012; Chang, 2019; Swain, 2009; Wijesinghe \& Mura, 2018). Growing numberswaves of scholars are now calling for a decolonization of tourism studies (e.g. Hollinshead, 2016; Wijesinghe et al., 2019), or for approaches that embrace cultural plurality and difference (e.g. Coles et al., 2006, 2016; Hollinshead, 2010; Mura \& Wijesinghe, 2019; Yamashita, 2019). With the aim of interweaving some of these threads of critical tourism studies, this article highlights some of the subtle ways in which our understanding of tourism in the Indonesia hinterlands continues to be filtered through an inherited, set of largely Western-generated, scholarly constructs. Moreover, this article advocates for a particular methodological approach as a strategy for fostering more nuanced understandings of travel behaviors that can ultimately help dislodge Western/Anglo-centrism in tourism studies: this approach entails foregrounding local knowledge and anthropological story-telling.

Drawing on thirty years of ethnographic research in the Toraja homeland of Sulawesi, Indonesia, online discussions, and face-to-face interviews with Torajan migrants who have journeyed home, this article spotlights Torajans' lived experiences pertaining to travel. My aim is to showcase how culturally-grounded understandings of travel can offset and challenge classic Western models which tend to define tourists as outsiders engaged solely in leisured pursuits. I offer analysis of several case studies selected as representingative of broader patterns observed over the course of decades of field research. Some of these ethnographically-grounded cases are presented in story-like fashion, which I argue is a potent but underrecognized avenue for conveying insights, fostering empathy and decentering the field. My overarching aim is to integrate locally-grounded cultural understandings of travel with broader politicaleconomic factors coloring their experiences (e.g. Gillen \& Mostafanezhad, 2019; Mostafanezhad, 2013; Sin, 2009; $\mathrm{Su}$ et al., 2018). The 'critical turn' has generally focused more on symbolic and cultural aspects of tourism (e.g. stressing hegemonic cultural imagery and discourses), often foregoing more penetrating analyses of "the asymmetries of power and divisions of labour that have grown under conditions of neo-liberal capitalism and globalization, and how these...manifest in specific tourism locations" (Bianchi, 2009, p. 487). This article seeks to interweave these two dimensions.

Before addressing the ethnographic material, a foray into the landscape of Asian critical tourism studies (A-CTS) is warranted. The idea of a "critical Asian tourism scholarship" is a recent endeavor (Chang, 2015, p. 84). Chang (2015) outlines two broad, sometimes-intersecting currents in A-CTS, one that interrogates the usefulness of orthodox Anglo-American constructs of Asian tourism-as productive for understanding Asian tourism dynamics (Winter, 2009; Winter et al., 2009), and a second, more radical current underscoring the need toimportance of Asianizeing the field (King \& Porananond, 2014; Teo \& Leong, 2006). As Chang observes, both currents signal not only desires to use scholarly knowledge to make a difference, but also recognition of the importance of foregrounding the diversity of "Asian" identities, perspectives, and experiences vis á vis tourism.

However, we might liken A-CTS to the kudzu vine - a creeping plant mythologized in American urban legends as an imported species that rampantly spread along rural highways and railroad embankments in AmericaUSA's Deep South. Like kudzu, from a certain standpoint, A-CTS approaches seem increasingly ubiquitous on the landscape. Yet, just as American scientists slowly came to realize that kudzu's all-enveloping spread was exaggerated, A-CTS's roots have not fully penetrated all realms of Asian tourism scholarship. As some have observed, A-CTS have flourished more along some byways than others (Mura \& Wijesinghe, 2019). For instance, Mura and Pahlevan Sharif (2015) note that while critiques of Western-centric tourism scholarship are increasingly rampant in "Western/Anglo" realms, "sadly these voices have been less incisive within the "non-western"/"colonized" tourism academic world, including Asia" (Mura \& Wijesinghe, 2019, p. 1). However unlike kudzu, which is generally disdained as a harmful invasive species, A-CTS offers great promise for yielding more insightful and (positively) impactful research.

\section{Organizing framework: gates and yellow brick roads}

This article draws on two framing images that are 'good to think' ('bonnes à penser'), to paraphrase Claude LéviStrauss's classic reference to forms that are productive for exploring broader social structures and formations (LéviStrauss, 1962). My first image is that of a gate, or gateway. As travelers, we are familiar with an assortment of gates, ranging from the gates of Jerusalem to welcoming gateway arches marking entry to tourist zones such as Chicago's Chinatown or Jakarta's Beautiful Indonesia Miniature Park. Yet these structures are not simply welcoming markers of inclusion: they can also contain human-made barriers. The ancient gates of once-walled cities like Jaipur and the contemporary gates of resorts and planned vacation communities remind us that gates not only mark "home" and "home communities"- that is, places of belonging - but also serve as edifices of control, regulating flows of people. In this 
vein, it pays to remember that gates are tethered to walls, the ultimate structures marking borders between insiders and outsiders. Recently, geographers have highlighted growing fixations on walls and wall-building as reactions to the "uncontrolled movement of individuals and non-state actors... [which] may be understood as a response to the decline of sovereign power in a globalized world... [where] 'enemy-others'... materialize in the figure of terrorists,... irregular (and errant) migrants" (Minca, 2017, p. 5). But as the Toraja case demonstrates, 'migrants' can also share terrain with the contrasting Western category of 'tourists' who are courted by nations and happily ushered through welcoming gateways.

Gates are more than sedentary markers. The very notion of a gate hinges on mobility: gates can open or close, controlling our moves between insider and outsider realms, and managing active congress between diverse peoples. Drawing on the framing image of gates enables contemplation of tourism's entwinement with privilege and inequality, migration and displacement. First, if we consider gates as material structures-ranging from bamboo to fortified steel-that are implanted in specific, legally dictated sites, we encounter politics, power and economics. Our scholarly perspectives on power set us apart from everyday tourists, enabling us to lend incisive insights into pressing issues. As Errington and Gewertz (1989) observed over 25 years ago, "If [we are]...to have anything of importance to say... we need to develop... a voice as politically informed as that of Jamaica Kincaid" (1989, p. 52). In short, critical tourism studies can offer crucial insights into how entitlements and exclusions of nationality, class, ethnicity, gender, and religion inform the social practices that undergird human lives. The Toraja cases presented here illustrate how legal status, cultural and financial capital heavily color the experiences of Toraja migrants returning for homeland visits. While poorer Torajan migrant laborers are less likely to have the ability to return home for leisure visits, wealthier Torajan return visitors often enjoy the cocooned comfort of air-conditioned hotels, interspersing sometimes stressful family visits and ritual duties with extensive touristic activities (see Adams, 2019).

We can also reflect on gates and gateways as betwixt-and-between liminal zones, where one leaves behind one realm to enter another. Arnold Van Gennep (1909) coined the term 'liminality' to describe ritual transitions or passages from one culturally-defined state to another: this ritual stage involves "creation of a tabula rasa, through the removal of previously taken for granted forms and limits" (Szakolczai, 2009, p. 148). Liminality removes novitiates from earlier roles, ways of thinking, and habitual practices, ultimately transforming them. Thus, as markers of liminal zones, gates remind us of a key contribution of critical tourism studies, and this article: to challenge deeply engrained binaries between North and South, East and West, tourists and migrants, home and away. This is an enterprise undertaken by ever-growing numbers of tourism scholars over the past two decades (e.g. Ashtar et al., 2017; Cohen \& Cohen, (Cohen and Cohen 2015), -2019; Franklin \& Crang, 2001). Yet, in an era characterized by simplistic "we"/"they" worldviews, it bears underscoring that scholarswe can play a vital role in moving students, policy-makers, and publics away from reductionist thinking that can often obscure deeper understandings.

Finally, just as gateways and their gates are implanted in soil, a distinctive strength of ethnographically-based tourism scholarship is its grounded-ness in people's everyday lives, in the mundane and momentous moments that offer insights into more charged, broader issues. Tourism ethnographers' abilities to convey and amplify the stories, textures, tastes, and feelings of those in whose lives we partake offers the promise of engendering empathy in an increasingly intolerant world. Recently, the field of anthropology (where ethnographic methodologies originated) nessed a small flurry of books pushing for an expanded vision of "the anthropologist as storyteller" (Gottlieb, 2016, p. 93; also see Narayan, 2007, 2012; Wulff, 2016). Anthropology's 1980s post-modern "crisis of authority" ultimately prompted anthropologists to "sharpen their writing tools" (Wulff, 2016, p. 3), paving the way for a wider range of acceptable genres for imparting ethnographically-honed insights, ranging from graphic novels to creative-nonfiction. Such story-oriented interventions have yet to hit tourism studies. While tourism scholars have examined storytelling as a creative, improvisational guiding practice merging entertainment and education (Wynn, 2005), as an avenue foror challenge to-destination-branding (Martin \& Woodside, 2011) or as central to tourist practices (Bruner, 2005; Chronis, 2005), less attention has been directed to storytelling's value as a scholarly strategy for destabilizing orthodox theoretical understandings. Via the-ease study stories of traveling and returning Torajans presented here, I suggest that ethnographic storytelling is one important yet under-explored pathway towards fostering a de-centering of Western-Anglo-centrism in tourism studies.

A second, subsidiary image framing this article is that of the 'yellow brick road.' For film buffs, these twin images of 'gates' and 'yellow brick road' will evoke the 1939 Hollywood film The Wizard of Oz, a tale of a Kansas farm girl, Dorothy, swept away by a tornado to thea distant Land of Oz. There, Dorothy and her newfound friends follow a meandering, perilous, yet promise-filled yellow brick road to reach the gates of the Emerald City, where they hope to 
realize their dreams. (For Dorothy, the dream is a return home to Kansas). Like Oz's proverbial 'yellow brick road,' tourism development was initially envisioned as a pathway to economic empowerment and nation-building in Indonesia (Soekarno n.d.; Picard, 1997; Adams, 1997, 2018). Yet just as Oz's yellow brick road was plagued by unanticipated twists, turns and detours, so too has been the story of tourism in these nations. Anchoring a Tourism Geographies article in images from an old musical about a displaced person may seem odd, but this film (centering on a voyage) can be instructive as a starting point for problematizing the persistent categories structuring our field. ${ }^{1}$

As tourism scholars, we've inherited sets of traditional Western-centric disciplinary and topical boundaries: we study tourists, be they "domestic" or "international," and we study touristic places. Also, depending on our disciplinary emphases, we study how tourists perceive, interact with, or transform host communities, be it economically, culturally or ecologically. Yet, Oz’s Dorothy, like many travelers, can blur our categories:- $€$ Though a displaced person facing possible permanent exile with no clear path home from $\mathrm{Oz}$, Dorothy occasionally adopts touristic gazes and enacts touristic behaviors (as when admiringly the Emerald City from a distance and later enjoying the city's novel delights that contrast with her grey, depression-era experience inrural Kansas home). How might expanding our traditionallyelassie narrow focus on 'tourists' to encompass a broader range of (im)mobilities-displacement, migration, exile-yield new insights? Some scholars have begun exploring this question in other parts of the world (e.g. Bloch, 2017; Coles \& Timothy, 2004,- Tie and Seaton, 2013 et thisit merits further examination in Indonesian contexts. As I will suggest, many Torajans' travel practices an $\equiv$ nceptions-and practices surrounding travel accommodate more overlap between tourism and migration than is typically captured viain our Western categorizations.

I argue that a "Toraja-centric" perspective highlighting the blurriness between tourism/migration can be instructive for correcting the one-size-fits-all binary divides between tourism and migration that have plagued classic Western models of travel. The Western academic history of narrowly defining tourism primarily in terms of recreational travel and excluding returning migrants from our lenses has hindered more nuanced understandings of contemporary travel dynamics in Toraja (and elsewhere in Indonesia). Moreover, contemporary post-colonial global labor and educational mobility have produced novel travel forms and behaviors that are betwixt and between the categories of "travel" and "migrant" return visits that western scholarship has classically treated as mutually exclusive. As I will illustrate, for first and second-generation Torajan migrants',-contemporary homebound trips entail interwoven activities (attending family funerals and visiting local tourism sites) that cannot neatly fit into the Western rubrics of "returning migrant" or "visiting friends and relatives" (VFR). Examining contemporary Toraja travel activities and attitudes from the ground-up underscores that travel patterns vary in different societies and are dynamic. In short, the Toraja case offers a corrective to classic, narrower Western-centric definitions of who is a tourist and what constitutes tourism.

The story of $\mathrm{Oz}$ is instructive in yet another way. While Dorothy and her friends focused on reaching their destination, the Emerald City, it turns out their journey along the yellow brick road was as important as their destination. With some exceptions, many of us in tourism studies habitually focus our lenses on tourist destinations, yet the Wizard of $\mathrm{Oz}$ reminds us that the pathways to and from those destinations-not just the destinations themselves-merit our scholarly attention. Thus, a secondary theme in this article entails exploring insights we might gain by focusing our lens on the trails and gateways to the ultimate destination, rather than squarely on the ultimate destination itself. Such a focus disrupts our habitual spotlighting of the dynamics at play in tourist zones, obliging us to better appreciate and more carefully attend to tourism's reverberations in out-lying zones.

\section{Methodology}

This study employed a mixed methods approach (Bernard, 2006): data collection involved a combination of ethnographic methods, in which participant observation (Spradley, 2016) figured prominently. Beginning in 1984-85 with biennial returns through 1998, and 2007, 2012, and 2017 visits, my participant observation in South Sulawesi spans three decades and informs my understanding of tourism and broader travel dynamics in and beyond the region. This long-term, grounded field research also lent insights into local ideas surround travel and locals' experiences of the overlapping terrain of tourism and migration in the Toraja highlands. My participant activities ranged widely. While residing with a rural highland Toraja family, I apprenticed with tourism carvers and souvenir vendors, attended government tourism planning meetings, guide workshops, cultural festivals, and over 70 Toraja rituals (which also drew return migrant participants who spent free hours touring their homeland with their offspring). I also joined formal tours alongside visiting return-migrants and participated in Toraja family trips to local tourism destinations (initiated 
when relatives returned for visits). These local destinations included Londa and Lemo's burial sites, Sa'dan weaving village, Mt. Sesean, Buntu Burake's giant Jesus statue, and Lolai, a "land above the clouds" sunrise vista site.

While some quantitative researchers bemoan ethnographic methods as too focused and specific to be replicated (Alder \& Alder, 1994, cited in Hollinshead, 2004), many observe that ethnographic methods are particularly valuable for illuminating people's often emotionally-charged experiences with challenges, disruptions, and change (Ellen, 1984). Thus, these methods are especially suitable for this study. Particularly when researching disenfranchised minorities or those with precarious legal statuses (such as tourist visa overstayers), reliable data is notoriously difficult to obtain via questionnaires and surveys. However, long-term participant observation fosters trust and more candid responses, thereby facilitating insights into topics not openly discussed in formal interview settings (Adams, 2012; Cole, 2004).

Due to the centrality of mobility as a research theme, data collection necessitated multi-sited ethnography (Marcus, 1995). While multi-sited (a.k.a. multi-local) research has its deepest roots in migration studies (e.g. Watson, 1977), and has also been adopted by geographers (e.g. Conran, 2011; Olwig, 2012), this technique has become prominent in tourism scholarship in recent decades (e.g. Adams, 2006; $\equiv$ ner, 2005; Haldrup \& Larsen, 2010). My research sites ranged from the Toraja highlands, to the road-stops al land capital) to Toraja, to first- and second-generation Toraja migrant homes in Makassar and Eastern Indonesia (Figure 1). I also visited Jakarta and Chicago migrant Torajans who recounted their returns to the ancestral homeland. Some of my field sites were not in the physical world but in the internet cloud. As a key meeting space where farflung Torajan migrants share memories and photos of travels home, the cyberworld of social media proved to be a fertile space for enriching my understanding of Torajan migrants' diverse experiences vis á vis their homeland. Although Indonesia is hailed as one of the world's most social-media active nations (Lim, 2013; Yogaswara, 2010), and had the third highest number of Facebook users in $2019,{ }^{2}$ scholarly examinations of Indonesian travelers' social media use to navigate experiences during homeland visits remain rare (but see Hamzah, 2013). This is surprising, since the cyber-world of social media offers a potentially fertile data source for these inquiries, particularly when used in triangulation with other data pools.

Figure 1. Map of South Sulawesi, indicating the Toraja highlands, Makasar and Stanis and Katrin's restaurant. Drawn by the late Stanis Sandarupa and used with permission from Dirk Sandarupa. 


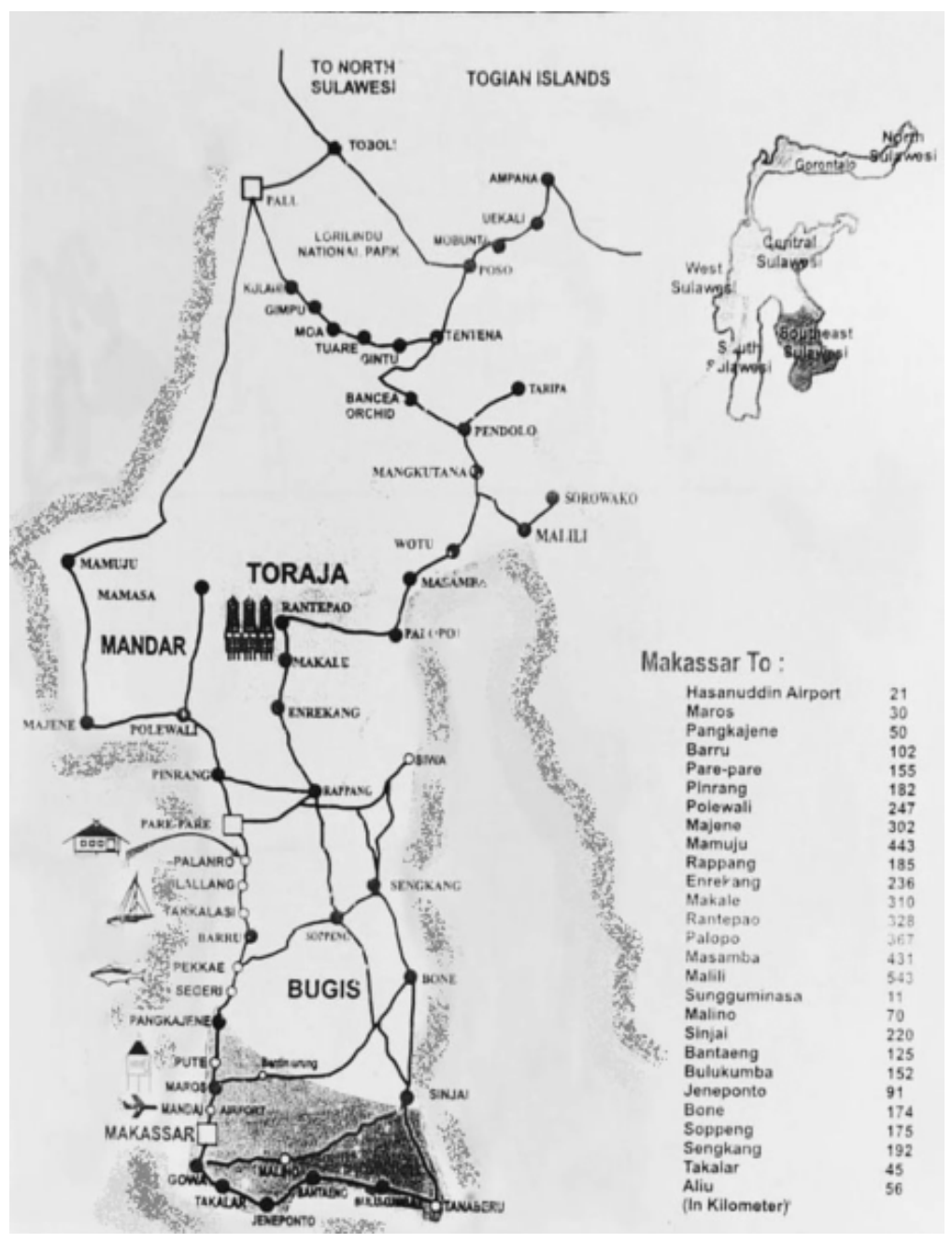

Formal and informal interviews (Gubrium \& Holstein, 2001) were also employed. I selected participants via a purposive sampling strategy (Cresswell \& Plano Clark, 2011). This technique entails identifying interviewees with extensive experience in the realm of one's study (Bernard, 2006). Interviewed with first and second generation Toraja migrants who had returned for visits to their ancestral homeland were in person and online (private and group interviews). A call for participants on Toraja migrant social media pages drew 59 interviewees. Most responded to an announcement on the largest Toraja migrant Facebook page-'"Worldwide Toraja Migrants United" (Persatuan Perantau Toraja Seluruh Dunia) — which boasts over 40,000 members. These interviews included three private group discussions in 2015 and 2016 consisting of 25, 15, and 7 migrants who shared their motivations for and experiences while returning home for visits. An additional 12 were interviewed privately via Facebook messenger and phone, to ensure validity of group interview findings and elicit more detailed commentary.

After the administrator of the "Worldwide Toraja Migrants United" Facebook group announced my presence and research goals, I scanned page postings for a three-month period (in 2015-2016). These routine scans attuned me to overarching themes in migrant homeland returns and helped inform subsequent formal-interview questions. However, I refrain from quoting directly from these Facebook postings due to ethical concerns stemming from the unlikelihood that all 40,000 members spotted periodic posts announcing my presence as a researcher. This caution was reinforced by Harng Luh Sin's (2015) observations concerning social media fieldwork ethics. As Sin observes, social media blurs the traditional divide between private and public spaces offering new data feasts yet also serving up an ethical "can of worms" (2015, p. 680). 
In 2017, an additional 22 informal face-to-face interviews were conducted with first- and second-generation Toraja migrants visiting tourist sites in the Toraja highlands, Rantepao cafes, local funeral rituals, an international music festival, and two popular rest stops en route to and from the ancestral homeland (a café in the adjacent regency and a Toraja-owned coastal restaurant). I also interviewed local government officials whose sectors encompassed tourism (including the Tana Toraja Regency leaders, North Toraja Regency Office of Tourism and Culture officials and four leaders in districts with tourist sites).

Additional data derived from focused life histories of returning Toraja migrants and tourists, as well as those hoping to improve their lives via tourism work. Howard Becker's (1970) classic observations about life history methodology still hold true: carefully collected life histories can disrupt researchers' preconceptions and enable us to reframe our categories of understandings and questions from the point of view of those whose lives we seek to understand. As Goodson surmises, "Life history, by its nature, asserts and insists that power[ful actors and interviewers] should listen to the people it claims to serve" $(20012016,131)$. I now turn to recount some stories culled from this fieldwork.

\section{Betwixt and between: an undocumented migrant caught in global political struc- tures finds solace and potential salvation via tourism}

In keeping with the Wizard of $\mathrm{Oz}$ theme of spotlighting the importance of looking beyond destinations to address roads (and experiences en route to destinations), my first story begins on a traveler's pathway, in the harsh fluorescent light of a security gate in Japan. There, a distraught Indonesian mother, Elsi, awaits return to her homeland after spending half her life in the United States. Elsi's situation-at an airport gate between two worlds-resulted from her involvement in several of the varied forms of mobility that characterize today's world: tourism, overseas education, and migration. While at this moment, Elsi is clearly not a tourist but a returning migrant, the life experiences that brought her to this juncture were tightly entwined with tourism. Two decades earlier, Elsi's father's tourism work was a launching pad for the family's migration. His part time tour-guide job in Indonesia funded his education at a respected regional Indonesian university. His foreign academic contacts, acquired through his tour guiding activities, helped him secure an overseas Ph.D. fellowship, which brought him and his family to the United States. Eventually, Elsi's father completed his degree and returned with his wife to Indonesia to operate a tour company and assume a professorship at a leading university, leaving Elsi behind to study in the United States. Instead, love intervened: Elsi wed a Honduran migrant, birthed several children, and began building a life in the undocumented Latino community of her American town, all the while pining for her parents and siblings in Indonesia. As she explained, she "longed to show her husband and kids the beauty of her [ancestral] homeland," but without legal papers, a visit home was too risky.

Some ten years after her parents' return to Indonesia, Elsi learned of her father's imminent death. Suddenly, the structural impediment that had kept her immobile - her undocumented status - seemed irrelevant. Using her old Indonesian passport and rush-order American passports for her three toddlers, Elsi and her children flew to Japan. At Narita's transit gate, however, a routine passport check revealed her expired American visa. Tearful and fearful as Japanese airport officials interrogated her, she clutched her children tightly, waiting to learn if they would be permitted to pass through the gates and on to her homeland. Elsi sent me several anguished texts between interrogations, wondering if she had "done wrong" by trying to quench her "longing" to see her father one last time.

Eventually, they were allowed passage through Narita's transit gate and, upon landing in Indonesia, Elsi's toddlers' American passports were stamped not with the permanent entries afforded returning migrants but with twomonth tourist visas. The security gate delay cost Elsi dearly: she reached home too late for a final embrace with her father. Instead, Elsi and her toddlers spent two bittersweet months with her mother, acquainting the children with their Indonesian kin as well as the tastes, smells and textures of their heritage, even visiting ancestral villages and tourist sites in her parents' homeland. While Elsi was a migrant who had returned home for her father's funeral, many of her activities in these months overlapped with those of tourists (discussed below). It was only when Elsi attempted to book a flight back to the United States that she learned her undocumented status rendered return impossible. Her husband's probationary status in the United States meantoffered neither legal means for him to bring them home, nor the ability to join them in Indonesia.

As the months of separation wore on, Elsi and her children moved in and out of despondency, feeling trapped at 'home' but not 'at home' in Indonesia. In our conversations during these limbo months, Elsi shared stories of longweekend trips with her children that combined village kin visits with tours of Toraja touristic destinations (orchestrated by her highland relatives, as is common on such visits). While primarily based in Makassar (the lowland provin- 
cial capital where she was reared), Elsi, her children, and her mother spent weeks in her father's natal highland village preparing his funeral and in her mother's highland home town. She recounted how, on this first visit and subsequent highland visits, visiting Toraja tourist sites became a source of solace and reconnection with her heritage. In her words,

Our first arrival in Toraja, it was all culture shocked (sic) for the kids. But they love more Toraja than Makassar. One of my kids loves animals and was not afraid of the pigs, chickens, wild dogs. The other love (sic) the adventures. They played with their cousins but just with laughter and smiles and hand signals with resulting adventures and wonderful memories for them. We were at OMG I forgot the name...[Simbuang] Batuallo [a Toraja gravesite and tourism destination]...We also went to Singki [a hill with a tourist pavilion overlooking Rantepao, North Toraja's capital], walking up the stairs. Passing the ancient grave[s]...[There] my mom and brother explained a bit about the Toraja culture. [My daughter] had so many questions...

On another Toraja highland visit, local relatives took Elsi and her children to visit Toraja's newest tourist destination inaugurated in 2015: a 40-meter-tall statue of Jesus hailed as the world's tallest Jesus statue. Via Facebook, Elsi shared photos of herself and her children posing at the statue's touristic gateway, explaining how her local cousins shared the cultural importance of saying tabe (excuse me) as they passed Toraja graves along the newly bulldozed tourist road to the site. She also sent photos of the sweeping vistas photos from the statue's base, describing her "pride" derived from "shar[ing] the beauty of [her Eparents' rural] homeland" with her American-born children. Elsi's experiences during her ancestral homeland visit on the occasion of her father's death are not atypical: Toraja firstand second-generation migrants' returns home are often sparked by desires to reunite with local kin or attend family rituals, but these visits also entail touristic activities and cultural heritage education for children reared abroad. This Toraja mélange of tourism and migrant return visits forto participate in family rites is perhaps best encapsulated by a 2012 Facebook post made by a visiting migrant Toraja during her return homeland visit for a relative's funeral. Sharing a photo of herself in traditional Toraja funeral attire standing in the ritual arena, she offers the caption "Being a tourist in my (own) home." (For additional details, see Adams, 2019) (Figure 2).[AQ3]

Figure 2. AToraja migrant visitor photographing a funeral. Photo by the author.

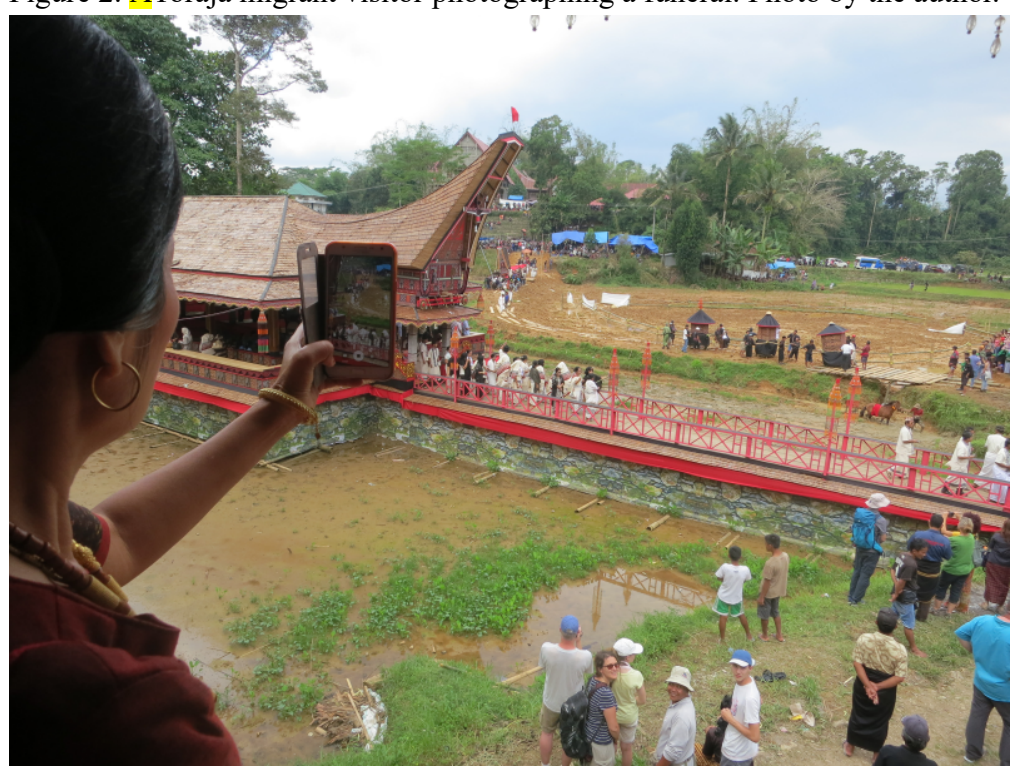

Elsi's subsequent experiences while in limbo in her homeland, unable to return home to her husband, illustrate how tourism can also serve as a "pathway" enabling migrants to regain equilibrium as they contemplate their next move. Using English and Spanish skills acquired as an undocumented migrant, Elsi toiled for almost a year in a tourist-oriented café in Sulawesi hoping that tourism-derived income and contacts might pave a path back to America, just as they had once done for her father during his tour-guiding years. In the meantime, Elsi's Facetime app becomes a nightly cyber gateway to her husband, making her fractured nuclear family momentarily whole again, albeit electronically. 
The betwixt and between-ness of Elsi's situation is hardly unique in the contemporary world. While tourists from affluent nations pass easily through airport gates, economically marginalized migrants seeking labor or love beyond their homeland borders can find themselves locked out. Writing on the intersections of Indonesian labor migrants and Singaporean sex and drug tourists on Batam Island in the Asian Growth Triangle, Johan Lindquist has movingly chronicled these 'anxieties of mobility' (Lindquist, 2009). Elsi's story, however, indicates different ways in which migration and tourism are co-entwined: Either embodied in the activities of a single individual (Elsi), or in the ironic passport statuses of three half-Indonesian toddlers residing in Indonesia with the legal status of foreign 'American tourists.' The toddlers' official status as foreigners poses a further economic burden on Elsi, as they must exit the country every three months to reactivate their tourist visas in order to remain with their mother. Elsi explains that these costly trips are not optional, as without valid identity papers, the children would have to forego schooling. So, for now, Elsi's children retain their status as American "tourists," and Elsi waits tourists' tables hoping to stave off a plunge into Indonesia's underclass. Stories like Elsi's remind us of ethnography's value in problematizing entrenched legal, political, and behavioral classificatory binaries such as "tourist" versus "migrant" that obscure far more complex realities.

Din (2017) recently explored the blurring between migrant return visits and tourism in the Malay world (encompassing Indonesia and Malaysia) via an auto-ethnographic examination of the Malay balik kampung tradition. Balik kampung is a Malay expression that refers to (migrants' returns to ancestral villages for holidays). Din ultimately suggests that this Malay/ndonesian migrant rite of holiday return visits to homeland villages constitutes a neglected form of tourism. His autoethnographic work offers an additional, related example of how Western orthodox categories of "tourist" versus "migrant" fail to capture on-the-ground realities in the Malay world (which includes Indonesia).

More broadly, it merits underscoring that the Indonesian/Malay term for migration (merantau) does not precisely map onto the terrain covered by the English term. Merantau is a widely used term generally defined as "leaving one's cultural territory voluntarily whether for a short or long time, with the aim of earning a living or seeking further knowledge or experience, normally with the intention of returning home" (Naim, 1976, p. 149-150). Today, merantau has become an Indonesian cultural institution (Lindquist, 2009): Indonesians use the term merantau to cover a wide array of mobilities, encompassing not only migration, but studying abroad and even long-term around-the-world type travels to gain experience and knowledge. Some scholars (Colombijn et al., 2012) gloss merantau as "wanderlust," which captures the historical salience of physical mobility in the Malay world. But I believe the notion of the 'quest' better conveys this cultural notion of travel as involving (a) undertaking movement in order to achieve some sort of transformation and (b) a vision of a final, permanent return home following achievement of the goal. (Although the Western notion of 'quest' does not assume that broad swaths of the population engage in this form of travel). Various scholars (e.g. Adams, 2016; Forshee, 2000) note that the overlay between merantau and tourism invites comparisons. Perhaps not surprisingly, the concept of merantau is "inscribed in Indonesian and Malay touristic culture, as [attested by] the existence of tourist-oriented lodgings [bearing the term] Merantau attest" (Adams, 2016, p. 19).

The practice of merantau was not widely adopted by Torajans until the 1970s and 1980s, when the suppression of regional Muslim armed rebellions, improved infrastructure, and new work opportunities in foreign-owned mines and timber industries made it viable for highlanders to seek fortune outside the homeland (Volkman, 1984, p. 158). Volkman characterized classic Toraja society as highly 'centripetal': in the pre-1980s era, most Torajans avoided travel and remained anchored to sacred ancestral sites and 'centers' in their homeland. She writes,

The most significant center was the ancestral house known as 'the place where the umbilical cord is buried' (inan larnunan lolo). The 'planting' of a newborn child's umbilical cord in the earth on the eastern side of the house metaphorically rooted the person to a particular place. Rituals reinforced the centripetal tendencies of Toraja life by periodically reconcentrating dispersed family members at the center, whether...[for] a funeral or a house-roofing celebration. The centripetal ideal was expressed in kinship as well: preferred marriages took place within the family and were known as 'returning to the house' [sulle langan banua]" (Volkman, 1984, p. 157-158).

Perhaps most significantly, Volkman-goes observes that

A centripetal, homeward-bound orientation is expressed even in the Toraja term for merantau: ma'lemba kalando; roughly, 'the long haul.' Ma'lemba means to carry something lashed to a bamboo pole across one's shoulder, and it 
evokes an image of a man returning from the fields with newly cut padi [rice stalks], bringing home the life-sustaining harvest" (Volkman, 1984, p. 158).

The paired Toraja conceptions of (1) family identity as rooted in physical places and (2) the life-sustaining role of returns home offer clues as to why contemporary migrant Torajans feel such strong affinities towards their homeland, and why they are drawn to travel home as return migrants cum tourists. Understanding these uniquely Torajan ideas regarding the magnetic pull of homeland hamlets also offers a corrective to the Western cookie-cutter divides between "tourism" and "migration." I turn now to another gateway that offers an entrée for exploring additional dynamics of migrant Torajan vacations in the homeland.

\section{Gateway to Toraja ancestral tourism: a migrant return festival embodies econom- ics, politics, and heritage-lite}

Just as Dorothy and her rag-tag companions experienced euphoria as they neared the gates of the Emerald City (the destination that offered the promise of realizing their desires), many visiting Torajans express similar emotions upon arriving at the monumental cement and wood gateway arch marking formal entry into the Toraja highlands (Figure 3). Hundreds of thousands of travelers have passed through this gateway since it was erected (originally in simpler form in the early 1980s, as part of the government's efforts to both mark district boundaries and welcome tourists). Over 800,000 Torajans live in the mountainous homeland, working predominantly as farmers or in civil service and tourism. Over one million more Torajans reside outside the homeland, many in cities and towns elsewhere in Indonesia or Malaysia, and others in more distant countries. Toraja out-migration began in the 1970s and soon thereafter migrant remittances began fueling ritual inflation, as successful first-generation migrants raise family status by funding elaborate homeland funerals, costing up to several hundred thousand dollars (Volkman, 1984). Remittances also inflate land and livestock prices, driving still more to emigrate (de Jong, 2013).

Figure 3. Gateway Arch marking entry to the Toraja highlands. Photo by the author. 


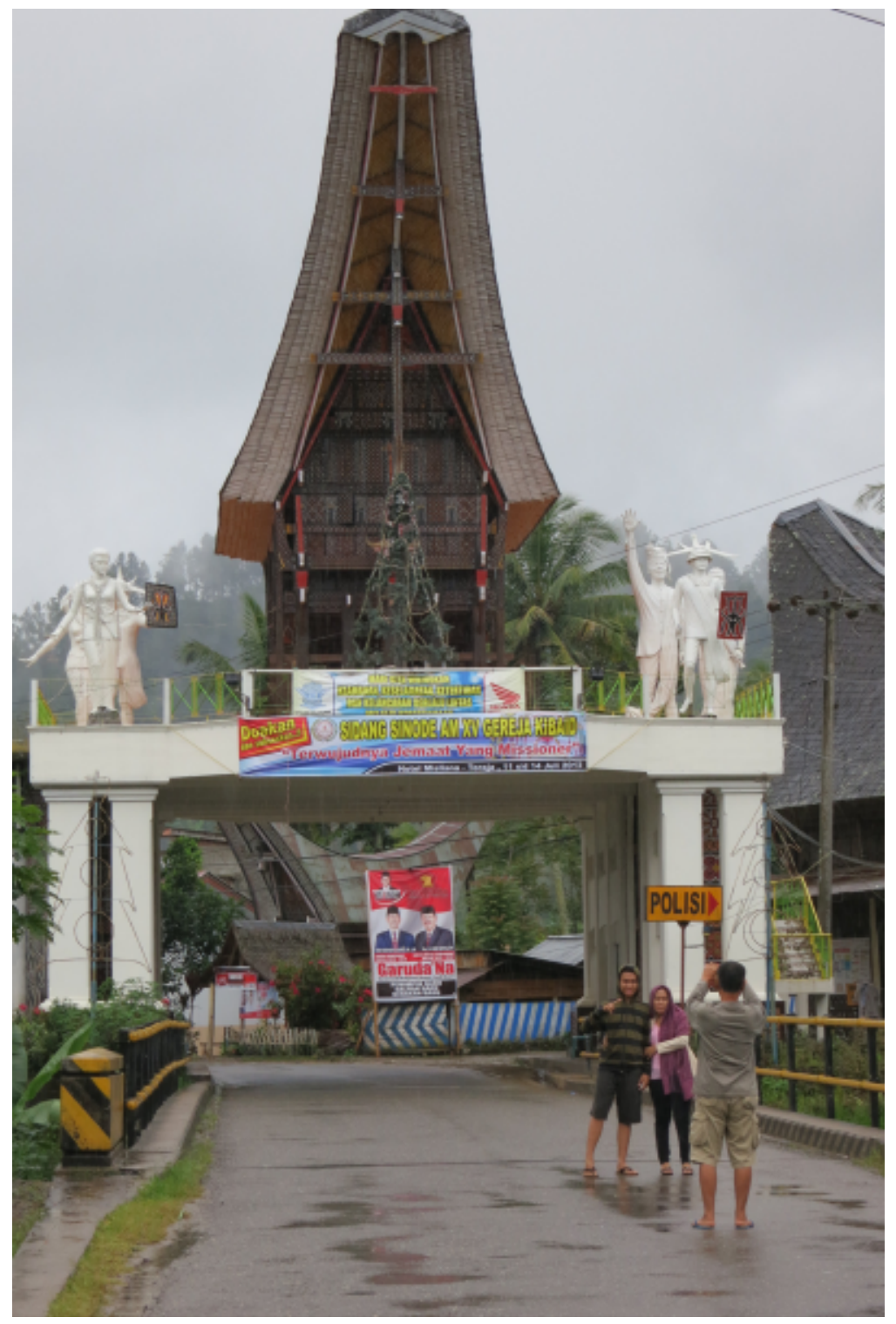

Yet, just as the spiraling costs of Toraja rituals propel some Torajans to become migrants, these very rituals and the region's spectacular landscape also draw tourists. (Table 1). Indonesia actively promoted international tourism to the Toraja highlands throughout the 1980s and 1990s, as: tourism was envisioned both as a revenue generator and an avenue for development promising, creating local job opportunities and raiseding income. At tourism's initial mid-1990s pinnacle, approximately 200,000 domestic tourists and 50,000 international tourists were visiting the Toraja highlands yearly. These internationally-derived categories of traveler types, long obscured awareness that a large percentage of those labeled "domestic tourists" were Toraja diaspora members returning home for visits (Adams, 1998). By the early and mid-2000s, however, the Indonesian economic and political crisis, ethno-religious tumult, Bali bombings, and other natural disasters slowed tourism to a trickle, puncturing the Toraja tourism economy. Thus, in 2006, local officials looked to a new, more reliable source of visitor-driven revenues. Ultimately, they hatehed a successful strategy they embraced was one they were well-positioned to appreciate as Torajans: courting new pools of Toraja migrants and their families back for vacations. Here we glimpse how "local knowledge," culled from growing up in a cultural milieu, enables insights into tourism dynamics fand potentials) (that are often externally imposed categorizations), a theme addressed in more detail in the final case. 
Table 1. Tourist arrivals in Toraja.

\begin{tabular}{|r|r|r|r|}
\hline Year & Foreign Domestic & Total \\
\hline 1983 & 9,007 & 57,957 & 66,964 \\
\hline 1984 & 12,547 & 84,338 & 96,885 \\
\hline 1985 & 15,325 & 70,987 & 82,312 \\
\hline 1986 & 19,726 & 113,590 & 133,316 \\
\hline 1987 & 22,108 & 168,985 & 191,903 \\
\hline 1988 & 25,308 & 154,865 & 180,173 \\
\hline 1989 & 32,566 & 152,927 & 185,493 \\
\hline 1990 & 39,700 & 171,689 & 211,389 \\
\hline 1991 & 40,695 & 174,542 & 215,237 \\
\hline 1992 & 46,799 & 171,172 & 217,971 \\
\hline 1993 & 51,259 & 195,544 & 246,803 \\
\hline 1994 & 56,565 & 204,987 & 261,552 \\
\hline 1995 & 59,388 & 176,849 & 236,237 \\
\hline 1996 & 42,123 & 32,930 & 75,053 \\
\hline 1997 & 41,586 & 42,578 & 84,164 \\
\hline 1998 & 22,624 & 30,597 & 53,221 \\
\hline 1999 & 30,397 & 31,415 & 61,812 \\
\hline 2000 & 37,805 & 32,207 & 70,012 \\
\hline 2001 & 37,142 & 34,218 & 71,360 \\
\hline 2002 & 30,058 & 32,638 & 62,696 \\
\hline 2003 & 15,385 & 27,520 & 42,905 \\
\hline 2004 & 5,762 & 21,802 & 27,564 \\
\hline 2005 & 5,385 & 19,933 & 25,318 \\
\hline 2006 & 5,321 & 20,817 & 26,138 \\
\hline 2007 & 4,989 & 13,102 & 18,091 \\
\hline 2008 & n.a. & n.a. & 25,583 \\
\hline 2009 & 5,499 & 34,716 & 40,215 \\
\hline 2010 & 5,627 & 12,631 & 18,258 \\
\hline 2011 & 21,027 & 40,037 & 61,064 \\
\hline 2012 & 25,652 & 35,263 & 64,880 \\
\hline 2013 & 35,956 & 70,128 & 112,223 \\
\hline 2014 & 41,058 & 71,522 & 112,580 \\
\hline 2015 & 43,575 & 87,462 & 131,037 \\
\hline 2016 & 51,793 & 112,628 & 164,421 \\
\hline 2017 & 62,356 & 223,210 & 285,566 \\
\hline 2018 & 44,425 & 235,712 & 235,712 \\
\hline & & & \\
\hline
\end{tabular}

Sources: Office of Tourism (1983-1989) \& Office of Statistics (1990-2010), Tana Toraja Regency, Indonesia. 20112018 data derive from North Toraja Regency Office of Statistics (reflecting Tana Toraja's division into two regencies).

In December of 2006, the local government staged its first annual migrant oriented 'Longing to Return Home to Toraja' (Toraja Mamali) festival. Using government funds and donations from wealthy Toraja migrants, the festival 
featured fireworks displays, migrant welcoming parades, traditional foods, dances, and hotel discounts for returnees and their families. Heavily promoted on Facebook and conventional news outlets, the festival was a tremendous success, dramatically boosting hotel bookings and restaurant revenues during tourism's slow season. As one Torajan migrant observed, "If you don't stay in the village (with local kin), it's hard to find a hotel room. So many migrants return for the festival..." Another second-generation Torajan migrant commented, "Though lots of Torajan [migrants] still visit home in the summer, the [December] Toraja Mamali Festival is really ramai (crowded/lively). Lots of us come home at Christmastime and attend the festival."

Further contextualization of the history of Torajan migrant return visits is necessary here. These visits fit under the broader Indonesian/Malay-based notion of pulang kampung (a.k.a. balik kampung) (re Din, ibid). Torajan homeland return visits typically occur in July and August during school vacations, and most highlanders schedule funerals and house rituals for these months to facilitate maximal familial participation (Torajans practice delayed burial, holding funerals months or years later). As Toraja kinship is structured around ancestral houses (all descendants of a particular ancestral house's founder are kin), maintaining membership in one's house-based families requires making potentially debt-inducing contributions to familial house-based rituals. For wealthier suceessful, first-generation migrants, returns for ceremonies offer not only occasions to amass prestige in the homeland via material and livestock contributions but also opportunities to tutor their foreign-born children in Torajan practices. As witnessed with Elsi, such heritage tutorials frequently transpire via touristic visits to Torajan cultural sites (which are generally interdigitated with family visits and funeral or house ritual participation). As a financially-comfortable migrant residing in Jakarta offered, "Most Torajans who migrate (merantau), if they have a chance to return home to Toraja their goal is to get together with family, and also [attend] rambu solo [funeral] or rambu tuka' [house consecration] rituals. But, Torajans also return for tourism, especially those who are married to non-Torajans, so that our partner can get to know Toraja."

However, for first-generation Torajan migrants without means, or for second-generation Torajans reared far from the homeland, the prospect of becoming entangled in ritual debt during summertime homeland visits can be distressing. A 44-year-old first-generation Torajan migrant's (whose remittances from cruise ship employment funded construction of his mother's houseme) comments capture the ambivalence many migrants attach to summer vacation/ ritual season visits,

I'm married now and support my wife and kids on Java and help my mother in the village [in Toraja]. I long to see my mother and my village, and for her to see my kids. I want my kids to know Toraja. But visiting in summer is too expensive. Not the travel, but she'll [mother] want me to give money for [extended family] rituals happening then. And how can I say 'no' to my mother who birthed me? It is better for my [nuclear] family that I stay with them [on Java, not visit Toraja in the summer ritual season]."

However, by scheduling the 'Longing to return home to Toraja' festival in December, when few Torajans hold funeral or house consecration rituals, Toraja migrants gained a festive framework for returning to their ancestral homeland strictly for leisure and heritage-exploration, without the economic burdens of ritual participation. A firstgeneration migrant's comments concisely capture the economic and cultural issues underlying the festival's appeal to migrants, "I don't want to oblige my kids to get tangled up in Toraja ritual customs [euphemism for getting encumbered with funeral debt], but the...festival interests me. There's art, Toraja clothing, bamboo music, traditional dances." As her comments suggest, the festival-based heritage experiences of visiting Torajans are generally aesthetic and sensual, yet anesthetized (Adams, 2019, p. 204). That is, the festival enables feasting on a smorgasbord of heritage, without the long-term indigestion entailed in funeral season visits, which inevitably and inextricably entwine returnees in the burdensome realms of funeral debts and local family political rivalries. In short, these migrant Torajan festivalgoers consume 'Heritage Lite' (Adams, 2019, p. 163).

While migrants' festival experiences enable them to sidestep the politics and economics normally entailed in return visits, the festival itself has not escaped these realms. After the successful 2006 "Longing to Return Home to Toraja Festival," the event became an annual affair. Two years later, in 2008, it was rebranded to attract a broader array of Christian Indonesian and international travelers. Renamed the "Lovely December" Festival, new advertising promoted the Christian Toraja highlands as the destination for ecumenical Christmas and New Year festivities in Muslim Indonesia. ${ }^{3}$ This economically-motivated ${ }^{\not}$ rebranding was not without politics. Externally initiated, funded and imposed by the non-Torajan lowland Makassarese governor of South Sulawesi, Syahrul Yasin Limpo, the rebranding prompted pleas from Toraja leaders in both highland Toraja districts to return to the festival's original migrant-homecoming focus. ${ }^{4}$ As one Toraja official lamented, 
"Before, there were so many migrants here for the festival that Rantepao traffic stretched from the Hotel Misiliana (at the city's southernmost edge) to the bridge over the Sa'dan river (at the city's northern end). And the city glowed with decorative lights! It was so ramai (crowded, bustling). Now, it is less interesting..."

Other Torajan officials echoed these sentiments, observing that the festival was at its liveliest and most bustling in its early years when its exclusive focus was welcoming home visiting migrants. Moreover, various Toraja officials stressed that, unlike the English language re-branding, the festival's original name reflected Toraja regional identity and Toraja "local wisdom" (Rante, 2016). A North Toraja Regency senator's response to the English "Lovely Toraja" festival captured many Torajans' sentiments, "It sounds so much more delicious (enak) to use Toraja Mamali (Longing to Return Home to Toraja) - the ingredient of Toraja local wisdom is palpable" (Rante, 2016). The trope of 'local wisdom' offers a tacit challenge tosignals-Torajans' historic position as provincial underdogs, historically dismissed as tribal others and long legacy of perceptions disenfranchised from political power-imbalances within the province (Adams, 2006; Biglke, 2005). As an ethnic and religious highland minority in a province long dominated by lowland Bugis and Makassarese, many Toraja leaders had believed their tourist drawing power (and concomitant contributions to state coffers) would grant them authority over the branding of their own festivals. However, the reality of their limited options given political and bureaucratic asymmetries at the provincial level was increasingly evidentnow became apparent.

The 2018 election of a new non-Torajan governor eager to imprint his mark on the political and touristic landscape brought another external rebranding of the festival as 'Kemilau Toraja,' or Toraja Glitter (sheen)" (Fajriani, 2018). Possiblyerhaps inspired by Indonesia'sthe national Ministry of Tourism and Culture's earlier embrace of "glitter" imagery for touristic festivals elsewhere (e.g. Erb, 2009), the new externally imposed rebranding was accepted by one of the two Toraja districts (Tana Toraja). However, Northern Toraja District rejected "Toraja Glitter," opting to remain with the previously imposed 'Lovely December' Festival branding. As tThey reasoned, that, at least, Lovely Decemaber had achieved name-recognition amongst returning migrants, domestic and international tourists. While the festival's name may seem trivial, the struggle embodies both economic agendas and political rivalries at the seale of the local, regional and the provincial levels. Moreover, the festival re-brandings also reveal a symbolic battle between Torajan officials and provincial-level tourism consultants regarding the merits of local versus outsider wisdom surroundingregarding the visitor drawing power of festival labels with the most visitor drawing power. InvokingReturning to the theme of the $\mathrm{Oz}$ and gateways framing, the touristic festival branding battles also remind us of the powereonstitutes a gateways-of sorts, shaping beckoning from magazine and internet pages forwhose travelers to embark en journeys to this highland destination. Of course, some gateways (branding imagery prevails) have more drawing power than others.

\section{Arung pala restaurant: learning from the road ${ }^{5}$}

Turning now from "gateways" to the second Oz frame of "yellow brick roads," we shift to the road running between Makassar (dubbed the island's lowland "gateway to Toraja") and the Toraja highlands. My aim here is to showcases the value of looking at the journey-and stopping points along the road traveled-rather than focusing solely on travelers' destinations.

Voyaging to the highlands entails a wearying nine-hour car or bus journey. The roadway hugs the coast for the initial three and a half hours, traversing Muslim Bugis and Makassarese lands, bustling county seats and slowerpaced towns, as well as shrimp hatcheries and rice farms. At the port city of Pare Pare, the road twists inland, winding north through gentle hills until it ultimately narrows and switchbacks its way up into the mountains. As the ribbon of land at the road's cliffside edge thins, each bend reveals increasingly dramatic vistas. Finally, the road plateaus briefly and one arrives at the decorative gateway marking entry to the Toraja highlands.

For many Christian Torajan travelers I interviewed, the lowland portion of the journey to the homeland was qualitatively distinct from the mountainous portion.- eEspecially in the 1980s, 1990s and early 2000s, Torajan comments about the lowland parsections of this road often conveyed-senses of mild unease. As one Torajan explained in 1986, "it is not until the bus turns inland and the air cools [with the ascent into the mountains] that I can relax." And as another Torajan recounted in 1998, "When we finally reach Bambapuang (an area in the rugged regency bordering Tana Toraja Regency), then I feel good [enak]. It's not like the earlier stops. There, I look forward to getting off the bus for a coffee and smoke. The Duri people there, they are a lot like us...even their sweets [depa' tori] resemble 
ours..." These and other Torajan comments reflect historical tensions and even mistrust between lowland Muslim groups and the predominantly Christian Torajan highlanders. For many travelling Torajans, the bus stops and rest stops along 'the yellow brick road' to the homeland marked far more than kilometers, they also marked a movement from lowland Muslim-dominated spaces of unease to higher altitude stops of growing comfort, both somatic (in terms of cooler temperatures) and psychological.

While space does not permit a full examination of the various stops along the route, here I focus on the transformations of one spot on this road that has shifted sensibilities concerning both the specific location and the journey to and from the Toraja highlands. A gateway frames this my final ethnographic story: This gatewaylt is not in a tourist destination but in the South Sulawesi District of Barru. ThisIt gateway marks entry to a restaurant on a lonely stretch of highway between Makassar and the Toraja highlands. The worn mosaic writing paving the restaurant's entryway reads 'ta pada salama' in Bugis Lontara script. The words bear multiple meanings - welcome, goodbye, and a prayer for safe travels. For local Muslim Bugis, they convey a prayer for the peace and safety of those entering and leaving. In 2000, in a period of inter-faith and inter-ethnic frictions elsewhere in Indonesia, Stanis Sandarupa, a Toraja professor-cum-travel agent who had migrated to Makassar as a young man, purchased the run-down café from its bankrupt owner, hoping to develop it into a destination restaurant. The site was far from his mountainous childhood Toraja homeland and from the city that had become his second home. Although two Bugis farming villages were nearby, the site promised no viable local clients. Moreover, despite the café's seaside backdrop, many South Sulawesi travelers found this stretch of the road "eerie" (sunyi). For most who plied the road, this was a not a destination, nor a rest-stop, but a 'pass though' zone.

Sandarupa's urban friends and realtives cautioned him against the purchase, warning him "Muslim Bugis locals would never buy food from a pork-eating Catholic family" and that (then-on-going) ethno-religious tumult elsewhere in Indonesia did not bode well for the venture. They feared he would be putting his family at risk as the only Christian Toraja entrepreneurs in the district. Yet Sandarupa held steadfast to his plan. He had studied ethnic relations in graduate school and, as he explained, he "knew ethno-religious violence rarely happened in places where one group was clearly dominant." This academically-based insight reinforced his culturally-honed instincts-or local knowledge - and went against the grain of commonly-taught Western tourism business strategies, which tend to emphasize 'location,' steady flows of tourists, supplies (for restaurants) and affordable labor.

Here, elaboration on the concept of local knowledge is needed. Generally, local knowledge refers to nuanced understandings of in situ sociocultural practices, be they spiritual, ecological, or economic. Such understandings are often intuitive rather than analytical and overlap with indigenous knowledge (Butler \& Menzies, 2007, p.18). As Butler and Menzies elaborate, both local knowledge and indigenous knowledge "have a sub-altern relationship with Western 'modern' scientific knowledge" (ibid, 7).

Sandarupa's inspiration for his traveler-oriented restaurant, as well as his innate understanding of how to achieve success, were grounded in local knowledge. His own experiences as a Toraja migrant who routinely moved between the lowland capital of Makassar and the highlands, like countless others, taught him that migrants would continue to travel this road, even when tourists were scarce. Sandarupa was also well-acquainted with the vague unease and mistrust many highland Torajans felt when traversing Muslim Bugis lowlands. He knew many Torajans preferred packing their own meals for the long nine-hour journey, rather than eating 'risky' food prepared by Bugis in what many imagined - rightly or wrongly-to be unsanitary roadside kitchens. As his mother-in-law once warned me when I was a graduate student new to the area, "Be careful where you eat at the Bugis bus stops, they wash with dirty water and never dry the plates - if you must eat there, do what we Torajans do, and eat only instant noodles [Indomie]." Stanis Sandarupa and his wife intuitively understood that a Toraja-owned restaurant on this lowland stretch of road roughly midway between the highlands and Makassar would attract a constant flow of hungry Toraja travelers. In addition, Sandarupa had observed his foreign tourist clients' penchant for sea vistas and calculated that they would also find the spot irresistible, since few roadside Bugis restaurants offered sea views. As he explained, "When I was a guide, I'd always stop on that stretch of the road, so the tourists could stretch by the sea-they always took a lot of photos."

After the Sandarupa family purchased the restaurant, they relocated there and sold snacks while slowly remodeling, sleeping together in the main room. As their son recounted, "it was a creepy place-naughty people [drunks, thugs and sex workers - the prior owners' clients] came there at night and my parents had to start closing early. Once they threw stones at the restaurant when we closed early." Given the restaurant's prior associations with illegal mischief (kenakalan), locals and police viewed the Sandarupa family with suspicion. Stanis tackled the situation by re- 
jecting the western 'time is money' business mantra. He began devoting long hours to daily visits, partaking in relaxed meandering conversations with local male villagers and authorities. These visits ultimately built trust and mutual respect. Stanis' wife, Katrin, also started spending days visiting the village women, exchanging recipes and coming to understand the texture of their lives. Both Stanis and Katrin were reared in rural areas and intuitively understood the cultural importance of these informal visits and leisurely conversations. Rather than foregrounding their still floundering restaurant's economic 'bottom line,' they nourished local social relations, buying vegetables and seafood from neighboring farmers and fishermen, selling villagers' baked goods at the café, going door-to-door with gifts of food on New Year's Day, donating to the mosque, and hosting community parties. As Stanis's wife Katrin summed up, "Now they trust us. Before, they did not want their teens to work for us, now they send them to seek work here." Gradually, they became valued members of the community; locals stage wedding receptions in their restaurant and officials now routinely bring guests to dine there.

By 2012, their café had blossomed into a thriving restaurant featuring locally-sourced food and the family felt secure enough to open small hotel adjacent to the restaurant. The site now bustles with transit buses and local customers, provides livelihood to twenty-six local employees, and is recognized by Barru Regency for its role in "transforming outsider perceptions of the area." As Sandarupa's son declares, they are becoming "Barru's tourist destination." For Torajan travelers, the restaurant is now a mini-destination and : it has transformeroded older concernssentiments about the ardors of travel through the lowlands. One Toraja friend recalled the first time she stopped there to break up the trip, "We had a picnic with the food we packed, sitting on a [covered open-air] platform by the sea. It felt cooler there, with the sea breezes. Katrin brought us drinks and some fresh fish. It was delicious." And as another Torajan woman explained, "Before, we'd have to pack our own food for the trip, and only drank coffee at the rest stops, but now we know we can eat good food [there]...we don't have to worry."

This is a small story in an out of the way place, but it is instructive, as it illustrates how attending to travelers' experiences and sensibilities along the road can lend insights otherwise overlooked when we focus solely on touristic destinations. Moreover, it demonstrates how "local knowledge" can lay the foundations for a mini-destination restaurant catering to locals, domestic and even international tourists. As a migrant with a foot in tourism, Sandarupa drew on his cultural and academic savvy to transform an ordinary road leading to a distant tourist destination into a promise-filled yellow brick road. Finally, tThis story of a roadside restaurant that evolved into a Barru tourist stop also underscores additional ways in which tourism and migration are entangled.

\section{Conclusion}

This article illustrates how ethnographic storytelling can serve as an important pathway towards fostering a decentering of Western-Anglo-centrism in tourism studies. Via ethnographically grounded stories of return migrant visitors, voyagers with problematic legal statuses, and travel-oriented café founders, I have highlighted Indonesians' lived experiences and locally-derived understandings of travel, thereby revealing some of the limitations of western definitions of tourism. As illustrated here, ethnographic storytelling has tremendous potential for not only conveying grounded insights about the ways in which culture, politics, and economics are entwined in specific tourist settings, but also for engendering empathy, an important but sometimes under-emphasized aspect of critical tourism studies.

Moreover, this study's findings problematize the deep-seated binaries that historically structured tourism research. Via the Oz-themed organizational frameworks of gates and yellow brick roads, I have highlighted some of the insights gleaned by adjusting our lens to focus less exclusively on inherited conventional categories like 'tourists,' 'tourism' and 'destinations.' When such generic categories are set aside and scholars embrace ethnography-based approaches foregrounding local knowledge, we gain more nuanced understandings of the culturally varied contours of travel. (As we saw, classic categories such as 'domestic tourist' versus 'international tourist' or 'visiting friends and relatives (VFR)' mask the more complex cultural themes, economic issues, and personal longings undergirding the homeland visits of Toraja migrants). Although a growing chorus of Asian critical tourism scholars has ve begun chipping away at these binaries, and more broadly at Western-generated one-size-fits all tourism models, categories, and understandings, there is still work to be done.

Notes

1. My selection of this Hollywood film captures some of the ironies and challenges inherent in efforts to "Asianize the field." I initially contemplated using an Asian film as an article "frame": the 2009 Indonesian film, Merantau 
(trans.: migration/quest). But Merantau is largely unknown outside Indonesia and would have necessitated a lengthy plot recitation, whereas the Wizard of Ox's familiarity to international audiences rendered it more serviceable for this journal's readership. Ironically, this calculus reflects how Anglo-Western publication contexts can vex desires to Asianize the field.

2. See https://www.statista.com/statistics/268136/top-15-countries-based-on-number-of-facebook-users/

3. https://www.indonesia.travel/gb/en/event-festivals/lovely-december-festival-2017-in-the-scenic-highlands-oftoraja

4. http://makassar.tribunnews.com/2016/01/31/toraya-mamali-atau-lovely-toraja-tokoh-toraja-ingin-kembali-mamali

5. An earlier article (Adams \& Sandarupa, 2018) concerning tourism entrepreneurship and local wisdom includes some of this data.

\section{Disclosure statement}

No potential conflict of interest was reported by the author.[AQ4]

\section{References}

Adams, K. M. (1997). Touting touristic "primadonas": Tourism, ethnicity, and national integration in Sulawesi, Indonesia. In M. Picard and R. Wood (Eds.), Tourism, ethnicity and the state in Asian and Pacific societies (pp. 155-180). University of Hawaii Press.

Adams, K. M. (1998). Domestic tourism and nation-building in South Sulawesi. Indonesia and the Malay World, 26(75), 77-96. https://doi.org/10.1080/13639819808729913

Adams, K. M. (2004). The genesis of touristic imagery: Polities and poeties in the creation of a remote Indonesian island destination. Tourist Studies, 4(2), 115 135. https://doi.org/10.1177/1468797604054378[AQ6]

Adams, K. M. (2006). Art as politics: Re-crafting identities, tourism and power in Tana Toraja, Indonesia. University of Hawai'i Press.

Adams, K. M. (2012). Ethnographic methods. In L. Dwyer, A. Gill and N. Seertaram (Eds.), Handbook of research methods in tourism: Qualitative and quantitative methods (pp. 339-351). Edward Elgar/Ashgate.

Adams, K. M. (2016). Tourism and ethnicity in insular Southeast Asia: Eating, praying, loving and beyond. Asian Journal of Tourism Research, 1(1), 1-28. https://doi.org/10.12982/AJTR.2016.0001

Adams, K. M. (2018). Revisiting 'wonderful Indonesia': Tourism, economy and society. In R. Hefner (ed.) Routledge handbook of contemporary Indonesia (pp. 197-207). Routledge.

Adams, K. M. (2019). 'Being a tourist in (my own) home': Negotiating identities and belonging in Indonesian heritage tourism. In Leite, N., Casteñeda, Q. and Adams, K. M. (Eds.), The ethnography of tourism: Edward Bruner and beyond (pp. 148-165). Lexington Books/Rowman and Littlefield.

Adams, K. M., \& Sandarupa, D. (2018). A room with a view: Local knowledge and tourism entrepreneurship in an unlikely Indonesian locale. Asian Journal of Tourism Research, 3(1), 1-26. https://doi.org/10.12982/AJTR.2018.0001

Alder, P. A., \& Alder, P. (1994). Observational technique. In N. K. Denzin, and Y. S. Lincoln (Eds.), Handbook of qualitative research (pp. 377-392). Sage.

Ashtar, L., Shani, A., \& Uriely, N. (2017). Blending 'home' and 'away': Young Israeli migrants as VFR travelers. Tourism Geographies, 19(4), 658-672. https://doi.org/10.1080/14616688.2016.1274775

Ateljevic, I., Pritchard, A., \& Morgan, N. (2007). The critical turn in tourism studies: Innovative research methodologies. Routledge.

Ateljevic, I., Morgan, N., \& Pritchard, A. (2012). The critical turn in tourism studies: Creating an academy of hope. Routledge.

Becker, H. (1970). Sociological work: Method and substance. Aldine. 
Bernard, H. R. (2006). Handbook of methods in cultural anthropology: Qualitative and quantitative methods. AltaMira Press.

Bianchi, R. (2009). The 'critical turn' in tourism studies: A radical critique. Tourism Geographies, 11(4), 484-504. https://doi.org/10.1080/14616680903262653

Biglke, T. (2005). Tana Toraja: A social history of an Indonesian people. Singapore University Press.

Bloch, N. (2017). Barbarians in India: Tourism as moral contamination. Annals of Tourism Research, 62, 64-77. https://doi.org/10.1016/j.annals.2016.12.001

Bruner, E. (2005). Culture on tour: Ethnographies of travel. University of Chicago Press.

Butler, C., \& Menzies, C. (2007). Traditional ecological knowledge and indigenous tourism. In R. Butler and T. Hinch (Eds.), Tourism and indigenous peoples: Issues and implications (pp. 15-27). Elsevier.

Chang, T. C. (2015). The Asian wave and critical tourism scholarship. International Journal of Asia Pacific Studies, 11(1), 83-101.

Chang, T. C. (2019). 'Asianizing the fileld': Questioning critical tourism studies in Asia. Tourism Geographies, 1-18. https://doi.org/10.1080/14616688.2019.1674370[AQ7]

Chronis, A. (2005). Co-constructing heritage at the Gettysburg storyscape. Annals of Tourism Research, 32(2), 386406. https://doi.org/10.1016/j.annals.2004.07.009

Cohen, E., \& Cohen, S. (2015). Beyond Eurocentrism in tourism: A paradigm shift to mobilities. Tourism Recreation Research, 40(2), 157-168. https://doi.org/10.1080/02508281.2015.1039331

Cohen, S., \& Cohen, E. (2019). New directions in the sociology of tourism. Current Issues in Tourism, 22(2), 153172. https://doi.org/10.1080/13683500.2017.1347151

Colombijn, F., Jaffe, R., \& Klaufus, C. (2012). Mobilities and mobilizations of the urban poor. International Journal of Urban and Regional Research, 36(4), 643-654. https://doi.org/10.1111/j.1468-2427.2012.01119.x

Cole, S. (2004). Shared benefits: Longitudinal research in Eastern Indonesia. In J. Phillimore and L. Goodson (Eds.), Qualitative research in tourism: Ontologies, epistemologies and methodologies (pp. 292-310). Routledge.

Coles, T., Hall, C., \& Duval, D. (2006). Tourism and post-disciplinary enquiry. Current Issues in Tourism, 9(4-5), 293-319. https://doi.org/10.2167/cit327.0

Coles, T., Hall, C., \& Duval, D. (2016). Tourism and post-disciplinarity: Back to the future? Tourism Analysis, 21(4), 373-388. https://doi.org/10.3727/108354216X14679788636113

Coles, T., \& Timothy, D. (2004). Tourism, diasporas and space. Routledge.

Conran, M. (2011). They really love me! Intimacy in volunteer tourism. Annals of Tourism Research, 38(4), 14541473. https://doi.org/10.1016/j.annals.2011.03.014

Cresswell, J., \& Plano Clark, V. (2011). Designing and conducting mixed methods research (2nd ed.). Sage.

Din, K. (2017). Returning home: A reflection on the Malaysian practice of balik kampung. Asian Journal of Tourism Research, 2(1), 36-49. https://doi.org/10.12982/AJTR.2017.0002

Ellen, R. (1984). Ethnographic research. Academic Press Inc.

Erb, M. (2009). Tourism as glitter: Re-examining domestic tourism in Indonesia. In T. Winter, P. Teo and T.C. Chang (Eds.), Asia on tour: Exploring the rise of Asian tourism (pp. 170-182). Routledge.

Errington, J., \& Gewertz, D. (1989). Tourism and anthropology in a post-modern world. Oceania, 60(1), 37-54. https://doi.org/10.1002/j.1834-4461.1989.tb00350.x

Fajriani, N. (2018, December). Sejarah Lovely December Program Andalan SYL, sekarang diganti Kemilau Toraja era NA (History of Lovely December SYL Mainstay Program, now replaces the Toraja Sparkle era NA). Tribun Timur. http://makassar.tribunnews.com/2018/12/03/tribunwiki-sejarah-lovely-december-program-andalan-syl-sekarangdiganti-kemilau-toraja-era-na

C Copyrights 2020 
Forshee, J. (2000). Shifting visions: Along the routes of Sumba cloth. The Asia Pacific Journal of Anthropology, 1(2), 1-25. https://doi.org/10.1080/14442210010001705900

Franklin, A., \& Crang, M. (2001). The trouble with tourism and travel theory. Tourist Studies, 1(1), 5-22. https:// doi.org/10.1177/146879760100100101

Gillen, J., \& Mostafanezhad, M. (2019). Geopolitical encounters of tourism: A conceptual approach. Annals of Tourism Research, 75, 70-78. https://doi.org/10.1016/j.annals.2018.12.015

Goodson, I. (2001). The story of life history: Origins of the life history method in sociology. Identity, I(2), 129 142. https://doi.org/10.1207/S1532706XID0102_02

Gottlieb, A. (2016). The anthropologist as storyterler. In H. Wulff (Ed.), The Anthropologist as writer: Genres and contexts in the twenty-first century (pp. 93-117). Berghahn.

Gubrium, J., \& Holstein, J. (2001). Handbook of interview research. Sage.

Haldrup, M., \& Larsen, J. (2010). Tourism, performance and the everyday: Consuming the orient. Routledge.

Hamzah, Y. (2013). Potensi media sosial sebagai sarana promosi interaktif bagi pariwisata Indonesia. Jurnal Kepariwisataan Indonesia, 8(3), 1-9.

Hollinshead, K. (2004). Ontological craft in tourism studies: the productive mapping of identity and image in tourism settings. In J. Phillimore and L. Goodson (Eds.), Qualitative research in tourism: Ontologies, epistemologies and methodologies (pp. 83-101). Routledge.

Hollinshead, K. (2010). Tourism studies and confined understanding: The call for a "new sense" postdisciplinary imaginary. Tourism Analysis, 15(4), 499-510. https://doi.org/10.3727/108354210X12864727693669

Hollinshead, K. (2016). Postdisciplinarity and the rise of intellectual openness: The necessity for "plural knowability" in tourism studies. Tourism Analysis, 21(4), 349-361. https://doi.org/10.3727/108354216X14600320851613

de Jong, E. (2013). Making a living between crises and ceremonies in Tana Toraja: The practice of everyday life of a South Sulawesi Highland Community. Brill.

King, V., \& Porananond, P. (2014). Introduction: Rethinking Asian tourism. In P. Porananond and V. T. King (Eds.), Rethinking Asian tourism: Cultures, encounters and local response (pp. 1-21). Cambridge Scholars Publishing.

Lévi-Strauss, C. (1962). Le totémisme aujourd'hui. [Totemism today]. Press Universitaire de France.

Lim, M. (2013). The internet and everyday life in Indonesia. Bijdragen Tot de Taal-, Land- en Volkenkunde / Journal of the Humanities and Social Sciences of Southeast Asia, 169(1), 133-147. https://doi.org/

$10.1163 / 22134379-12340008$

Lindquist, J. (2009). The anxieties of mobility: Migration and tourism in the Indonesian borderlands. University of Hawai'i Press.

Marschall, S. (2017). Tourism and memories of home: Migrants, displaced people, exiles and diasporic communities, Channel View Publications.

Marcus, G. (1995). Ethnography in/of the world system: The emergence of multi-sited ethnography. Annual Review of Anthropology, 24(1), 95-117. https://doi.org/10.1146/annurev.an.24.100195.000523

Martin, D., \& Woodside, A. (2011). Storytelling research on international visitors: Interpreting own experiences in Tokyo. Qualitative Market Research: An International Journal, 14(1), 27-54. https://doi.org/ $10.1108 / 13522751111099319$

Minca, C. (2017). Walls! Walls! Walls! Society and Space. http://societyandspace.org/2017/04/18/walls-walls-walls/

Mostafanezhad, M. (2013). Getting in touch with your inner Angelina': celebrity humanitarianism and the cultural politics of gendered generosity in volunteer tourism. Third World Quarterly, 34(3), 485-499. https://doi.org/ 10.1080/01436597.2013.785343

Mura, P., \& Pahlevan Sharif, S. (2015). The crisis of the "crisis of representation": Mapping qualitative tourism research in Southeast Asia. Current Issues in Tourism, 18(9), 828-844. 
Mura, P., \& Wijesinghe, S. (2019). Behind the research beliefs and practices of Asian tourism scholars in Malaysia, Vietnam and Thailand. Tourism Management Perspectives, 31, 1-13. https://doi.org/10.1016/j.tmp.2019.03.009

Naim, M. (1976). Voluntary migration in Indonesia. In A. Richmond and D. Kubat (Eds.), Internal migration: The new world and the old world. Sage Studies in International Sociology. 4.

Narayan, K. (2007). Tools to shape texts: What creative nonfiction can offer ethnography. Anthropology \& Humanism, 32(2), 130-144. https://doi.org/10.1525/ahu.2007.32.2.130

Narayan, K. (2012). Alive in the writing: Crafting ethnography in the company of Chekhov. University of Chicago Press.

Olwig, M. (2012). Multi-sited resilience: The mutual construction of "local" and "global" understandings and practices of adaptation and innovation. Applied Geography, 33, 112-118. https://doi.org/10.1016/j.apgeog.2011.10.007

\section{Pearee, D. (2002). Tourism and the periphery: Perspectives from Asia and the South Pacific. Tourism and Hospitality} Research, 3(4), 295 309. https://doi.org/10.1177/146735840200300402

Picard, M. (1997). Cultural tourism, nation-building, and regional culture: The making of a Balinese identity. In M. Picard and R. Wood (Eds.), Tourism, ethnicity and the state in Asian and Pacific societies (pp. 181-214). University of Hawai'i Press.

Rante, Y. (2016). Toraya Mamali atau Lovely Toraja? Tokoh Toraja ingin kembali Mamali. (Toraya Mamali or Lovely Toraja? Toraja leaders want Mamali back). Makassar Tribune. January. http://makassar.tribunnews.com/ 2016/01/31/toraya-mamali-atau-lovely-toraja-tokoh-toraja-ingin-kembali-mamali

Tie, C., \& Seaton, T. (2013). Diasporic identity, heritage, and "homecoming": How Sarawakian-Chinese tourists feel on tour in Beijing. Tourism Analysis, 18(3), 227-243. https://doi.org/10.3727/108354213X13673398610538

Sin, H. L. (2009). Volunteer tourism: "Involve me and I will learn? Annals of Tourism Research, 36(3), 480-501. https://doi.org/10.1016/j.annals.2009.03.001

Sin, H. L. (2015). "You're not doing work, you're on Facebook!": Ethics of encountering the field through social media. Professional Geographer, 67(4), 676-685.

Spradley, J. (2016) [1980]. Participant observation. Waveland Press.

Su, R., Bramwell, B., \& Whalley, P. (2018). Cultural political economy and urban heritage tourism. Annals of Tourism Research, 68, 30-40. https://doi.org/10.1016/j.annals.2017.11.004

Soekarno. (n.d.). President Soekarno on economic defensibility/Tourism in Indonesia. Ministry of Information, Republic of Indonesia. Special issue No. 15.

Swain, M. (2009). The cosmopolitan hope of tourism: Critical action and worldmaking vistas. Tourism Geographies, 11(4), 505-525. https://doi.org/10.1080/14616680903262695

Szakolczai, A. (2009). Liminality and experience: Structuring transitory situations and transformative events. International Political Anthropology, 2(1), 141-172.

Teo, P., \& Leong, S. (2006). A postcolonial analysis of backpacking. Annals of Tourism Research, 33(1), $109-131$. https://doi.org/10.1016/j.annals.2005.05.001

Van Gennep, A. (1909). Les rites de passage. [Rites of passage]. Émile Nourry.

Volkman, T. (1984). Great performances: Toraja cultural identity in the 1970s. American Ethnologist, 11(1), $152-169$. https://doi.org/10.1525/ae.1984.11.1.02a00090

Watson, J. (Ed.). (1977). Between two cultures. Blackwell.

Wijesinghe, S., \& Mura, P. (2018). Situating Asian tourism ontologies, epistemologies and methodologies: From colonialism to neo-colonialism. In Mura, P. \& Khoo-Lattimore, C. (Eds.), Asian qualitative research in tourism: Ontologies, epistemologies, methodologies and methods (pp. 95-115). Springer.

C Copyrights 2020 
Wijesinghe, S., Mura, P., \& Culala, H. (2019). Eurocentrism, capitalism and tourism knowledge. Tourism Management, 70, 178-187. https://doi.org/10.1016/j.tourman.2018.07.016

Winter, T. (2009). Asian tourism and the retreat of Anglo-western centrism in tourism theory. Current Issues in Tourism, 12(1), 21-31. https://doi.org/10.1080/13683500802220695

Winter, T., Teo, P., \& Chang, T. C. (2009). Asia on tour: Exploring the rise of Asian tourism. Routledge.

Wulff, H. (2016). The anthropologist as writer: Genres and contexts in the twenty-first century. Berghahn.

Wynn, J. (2005). Guiding practices: Storytelling tricks for reproducing the urban landscape. Qualitative Sociology, 28(4), 399-417. https://doi.org/10.1007/s11133-005-8365-2

Yamashita, S. (2019). Southeast Asian tourism from a Japanese perspective. In M. Hitchcock, V. King and M. Parnwell (Eds.), Tourism in Southeast Asia: Challenges and new directions (pp. 189-205). NIAS Press.

Yogaswara, A. (2010). The power of Facebook: Gerakan 1,000,000 Facebookers. Mediakom.

\section{AUthor QUeries}

Query: AQ0: Please review the table of contributors below and confirm that the first and last names are structured correctly and that the authors are listed in the correct order of contribution. This check is to ensure that your names will appear correctly online and when the article is indexed.

\section{Sequence Prefix Given name(s) Surname Suffix}

\begin{tabular}{l|l|l|}
\hline 1 & Kathleen M. & Adams \\
\hline
\end{tabular}

\section{Author Response: Ok}

Query: AQ1: Please check whether the author names (first name followed by last name) and affiliation are correct as presented in the proofs.

Author Response: Ok

Query: AQ2: Please provide the missing department name for author affiliation "a".

Author Response: Here is the missing department: Department of Anthropology (However, if this is meant to be a mailing address, it is incomplete. This is the complete mailing address:Dept. of AnthropologyLoyola University Chicago1032 W. Sheridan Rd., Chicago, IL 60660

Query: AQ3: Figure 2 was not cited in the text so a citation has been inserted. Please provide a correction if this is inaccurate.

Author Response: This is fine.

Query: AQ4: A disclosure statement reporting no conflict of interest has been inserted. Please correct if this is inaccurate.

Author Response: Ok

Query: AQ5: Please provide a short biography of the author in the "Notes on contributor" section.

Author Response: I do not see a Notes on Contributor section. Nor do I see the acknowledgements that I'd provided. I have added a comment by my name, just under the title. My bio and Acknowledgements are both there. Please insert them where they each belong. THANK YOU!

Query: AQ6: References “Adams (2004), Cohen and Cohen (2015), Goodson (2001), Marschall (2017), Pearce (2002), and Tie and Seaton (2013)" are listed in the references list but are not cited in the text. Please either cite the references or remove them from the references list.

Author Response: I took care of all of them...but there is one issue. I accidentally deleted the Goodson reference and should not have done so. I could not figure out how to undelete it. PLease make sure that it remains in the bibliography. THANKS!

Query: AQ7: Please provide missing volume number for the "Chang (2019)" references list entry. 
Author Response: THis appeared in a special online issue of Tourism Geographies--the same issue that my article is to be added to. There is no volu,e

\section{COMMENTS}

C1 Author: Although I had acknowledgements and my bio on the cover page that was submitted with this article, they both seem not to have been included. I would very much like to have the acknowledgements included with the article. I am not sure where they belong. If there is not a convention, I am assuming you can make them into the first footnote? Here is the cover page with both my bio AND the acknowledgements. Please use the wording on this version of the cover sheet, rather than the earlier one...as I realized I'd neglected to thank one important group.; C2 Author: Please link this to the reference in the bib that had been flagged as not being in the text. Note that in the bib Tie and Seaton is currently not in alphabetical order. Please also place the reference in alphabetical order in the bib, as per the note there. Thanks!;

C3 Author: Please link this to Adams 2006 in the bib--it was removed for peer review and needs to be reinserted. Thanks.;

C4 Author: PLease do not delete this reference--it was deleted in error. I found the quote in the text after deleting it accidentally. I can't figure out how to undelete this reference. Thanks!; 